\title{
Miranda
}

Revue pluridisciplinaire du monde anglophone /

Multidisciplinary peer-reviewed journal on the English-

speaking world

19 | 2019

Rethinking Laughter in Contemporary Anglophone Theatre

\section{Silvia Pellicer-Ortín, Julia Tofantšuk (eds.), Women on the Move. Body, Memory and Femininity in Present- Day Transnational Diasporic Writing.}

Sara Strauss

\section{OpenEdition \\ 1 Journals}

\section{Electronic version}

URL: http://journals.openedition.org/miranda/22300

DOI: $10.4000 /$ miranda.22300

ISSN: 2108-6559

Publisher

Université Toulouse - Jean Jaurès

Printed version

Date of publication: 7 October 2019

\section{Electronic reference}

Sara Strauss, "Silvia Pellicer-Ortín, Julia Tofantšuk (eds.), Women on the Move. Body, Memory and Femininity in Present-Day Transnational Diasporic Writing. ", Miranda [Online], 19 | 2019, Online since 15 October 2019, connection on 16 February 2021. URL: http://journals.openedition.org/miranda/22300 ; DOI: https://doi.org/10.4000/miranda.22300

This text was automatically generated on 16 February 2021.

\section{cc) (†)}

Miranda is licensed under a Creative Commons Attribution-NonCommercial-NoDerivatives 4.0 International License. 


\section{Silvia Pellicer-Ortín, Julia Tofantšuk (eds.), Women on the Move. Body, Memory and Femininity in Present-Day Transnational Diasporic Writing.}

Sara Strauss

\section{REFERENCES}

Silvia Pellicer-Ortín, Julia Tofantšuk (eds.), Women on the Move. Body, Memory and Femininity in Present-Day Transnational Diasporic Writing (New York: Routledge, 2019), 266 p., ISBN: 978-1-138-32199-1 


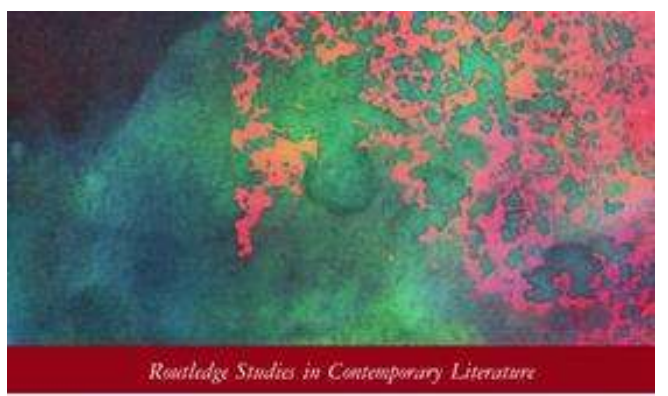

WOMEN ON THE MOVE

BODY, MEMORY AND FEMININITY IN PRESENT-

Edited by

Silvia Pellicer-Ortin and Julia Tofantšuk

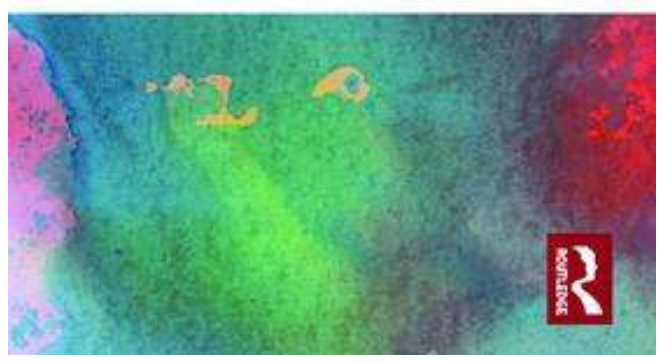

1 At a time when political conflict, persecution, environmental and economic factors cause millions of people to migrate from their homeland to seek refuge in other countries, Silvia Pellicer-Ortín's and Julia Tofantšuk's edited volume addresses the vast complexity of transnational migration and exile as presented in diasporic writing. It particularly focuses on the situation of female migrants and their experiences during migratory movement and life in the diaspora. Thereby, the collection responds to the urgent demand to include a gender approach in the fields of Migration and Diaspora Studies. Due to intersectional aspects that mark their identities, displaced women often encounter even more difficulties and disadvantages than male migrants. As a result of overlaps in differentiating factors, such as gender, race, class, age, religion etc., migratory females are at a high risk of abuse, exploitation and discrimination in their native countries as well as on their journeys and in the states of their destination. For this reason, the volume aims at problematising the situation of female migrants both during their transnational movements and in the diaspora.

2 Writers and scholars in disciplines such as sociology, cultural studies and postcolonial studies, among others, have adverted to the importance of representation for political participation, equality and empowerment (Adichie, 2009, Hall, 1997). The present collection therefore moves the literary representation of female migratory experience into the centre of attention. In line with Derek Attridge's argument that literature offers more vivid and emphatic approaches to ethical considerations than philosophy (Attridge, 2004), the book examines the narrative representation of migration in fiction and semi-autobiographical writing. It thus investigates the power of narrative to offer different perspectives on the diaspora and create empathy with characters experiencing suffering, exploitation and displacement.

3 The collection is divided into five thematic sections, which are preceded by a preface and an introduction by the two editors. In her foreword Jill Lewis praises the timeliness 
of the book and points out its importance as regards the necessity of interrogating political hierarchies. She draws attention to the volume's role as a forerunner beyond the scope of the book itself in inspiring a critical reflection on current attitudes towards refuge seeking and responses to migration. Subsequently, Pellicer-Ortín's and Tofantšuk's introduction gives an overview on the complexity of the topic of migration and discusses crucial issues with regard to transnationality, exile and diasporic life. It foregrounds the interrelation between the experiences of displacement and trauma. In this context, the two editors convincingly argue for a feminist perspective when examining mechanisms of discrimination and exploitation throughout processes of migration. They then provide the theoretical basis for the following essays. As such, aspects of female migratory practices are considered against the background of theories of identity, agency, history, memory, trauma, the body and the significance of space.

The twelve contributions that form the main part of the volume analyse the literary representation of female migrants as portrayed in the works of diasporic writers of African, Caribbean, European, Latin American and South Asian origin. The selection of narratives discussed offers fruitful insights into a great variety of cultural backgrounds as the individual chapters study literature by authors originating from, among others, Bangladesh, Haiti, Hungary, India, Ireland, Jamaica, Nigeria and Zimbabwe now living in the United States and the UK. Thus, the two essays of the first section address transnational women's struggles for identity and agency despite feelings of displacement and unbelonging. While skilfully demonstrating the aesthetic and ethical meaningfulness of selected coming-of-age stories by Chris Abani, Chika Unigwe and NoViolet Bulawayo, Cédric Courtois and Merve Sarikaya-şen problematise the protagonists' experiences of abuse, migratory trauma and alienation from their home as well as their host country.

5 Section Two deals with mobility as constitutive of personal identity. Beatriz Pérez Zapata's contribution examines Zadie Smith's novels with regard to movement and feelings of rootlessness in global and glocal societies. In her analysis of Swing Time, she relates movement, both spatial and temporal, to freedom, autonomy and agency and exemplifies in how far Smith's characters struggle to find a balance between acknowledging the history of their ancestors for their own sense of self and the limitations that their roots entail for them. The following essay by María Rocío CoboPiñero problematises Western notions of cosmopolitanism with regard to secondgeneration diasporic subjects. It contrasts Taiye Selasi's concept of Afropolitanism, which is criticised for its elitist focus on privileged middle-class citizens and its neglect of the challenges associated with gender stereotypes and undocumented immigration, to Selasi's more multidimensional representation of fictional transnational characters in her novel Ghana Must Go (2014).

6 In section Three the essays by Corinne Bigot and by Chiara Battisti and Sidia Fiorato consider the interrelations of gender, identity and the spaces of the home and kitchen. In their analyses of narratives by Edwidge Danticat, Chitra Banerjee Divakaruni and Chimamanda Ngozi Adichie (Bigot) as well as Monica Ali (Battisti and Fiorato), they demonstrate how far the cultural practices of preparing and consuming food serve to maintain the indigenous traditions as well as emotional ties with the homeland or with family relations, or to adapt to the new country. 
7 The fourth section, then, focuses on Irish as well as Jewish-Hungarian experiences of in-betweenness as represented in novels by Edna O'Brien, Colm Tóibín, Anne Enright and Charlotte Mendelson. Whereas Maria Amor Barros-del Río's chapter concentrates on twentieth-century female emigration from Ireland to the United States, Selen Aktari-Sevgi discusses liminality as a constitutive part of Irish women's experience during the decades around the turn to the twenty-first century. Both contributions show to what extent Irish women were and are challenged by the restrictive ideologies of the Irish nation project and its discourses (Barros-del Río) and the oppressive neoliberal ideologies of the Celtic Tiger period and its aftermath (Aktari-Sevgi). Subsequently, Julia Tofantšuk's essay complements the preoccupation with the interrelation of memory and identity evident in the preceding sections with a view on the effects of forgetting as a catalyst for conflict. In her precise analysis of HungarianBritish writer Charlotte Mendelson's novel Almost English, Tofantšuk exemplifies the psychological effects of repressed traumatic memory of the individual and its collision with collective memories within the diaspora. Through cross-references to theories, ideas and arguments presented in further chapters of the volume, the contribution also manages to show interrelations between the different diasporic conditions while enriching the scope of the collection with an example of migration within Europe.

Section Five elaborates on the motif of border crossing in literature of diverse cultural backgrounds. In their contribution Paul Rüsse and Maialen Antxustegi-Etxarte Aranaga address a historically and presently much-debated border region: the US-Mexican border. They advert to the triple oppression of Chicanas due to their working-class background, their skin colour and gender. Yet, using the example of Ito Romo's short stories the authors manage to unveil how this gendered discrimination is subverted in Chicano/a literature. The following essay by Carolina Sánchez-Palencia discusses West Indian labour immigration to Britain during the post-war years as represented in Andrea Levy's novel Small Island. By means of her careful narrative analysis SánchezPalencia demonstrates that Levy's diasporic fiction "contest[s] the linear and dominant narratives of patriarchal and imperial discourse" (222). The final chapter of the volume authored by Silvia Pellicer-Ortín, then, considers Jewish female identity in Michelene Wandor's short story collection False Relations and demonstrates that, in the absence of a shared language or country of residence, experiences of migration and crossculturality are characteristic of Jewishness and Jewish communities. Through her accurate narratological analysis Pellicer-Ortín manages to unveil that the plurality of voices, spaces and time spans as well as the formal aesthetics and complex structure of Wandor's collection recreate the multidirectionality and transculturality of Jewish memory and identity.

9 In sum, the edited volume must be praised for its bold endeavour to discuss and acknowledge a great variety of visions of transnational diasporic life and include views from multiple cultural backgrounds. Thereby, this collection helps to prevent "the danger of a single story" as Chimamanda Ngozi Adichie famously warned against a simplistic, stereotypical depiction of former colonial countries and their people (2009). Especially with regard to the anti-immigration political agenda of Brexit and the presidency of Donald Trump in the United States as well as the resurfacing of nationalist ideological discourses in several European states, the book receives a sad topicality. Consequently, the relevance of the present collection and of literature that 
creates empathy with people experiencing the challenges of migration and displacement cannot be underestimated.

INDEX

Mots-clés: diaspora, migration, exil, études de genre, féminité, mémoire, identité, trauma, littérature, fiction, récit

Keywords: diaspora, migration, exile, gender studies, femininity, memory, identity, trauma, literature, fiction, narrative

\section{AUTHORS}

\section{SARA STRAUSS}

Research Assistant

University of Paderborn - Germany 